\title{
The Influence of the Media on the Contemporary Art and on Graphic Arts in Particular in Bulgaria
}

\author{
Nikolina Djanovska ${ }^{a}$
}

\begin{abstract}
What is the influence of the media as a means of work today? Media as a material (paper, canvas, vinyl, etc.) on which it is printed, with its specific characteristics and special features-texture (plain, uneven, with a defined relief), colour shade, and even thickness; media as a means of documentation of the result of the creative process through catalogues; media as a mediator representing the result of this process in the common cultural sphere. How powerful is the media? There is one thing happening at the moment of "the event occurring" in the institution (a gallery, an exhibition hall, etc.). It is performed, reproduced, eventually sold. Otherwise it does not exist-it is not paid attention in the media, it is released nowhere (it is nowhere "published"), respectively it does not influence anybody and does not justify the use of its existence.
\end{abstract}

\section{Keywords}

Media, contemporary art, graphic art

The medium through which the artist expresses $\mathrm{him} /$ herself is very important. The problem lies in the first stroke made by the prehistoric man. Starting from the ancient times and cave-painting art until the modern days and the realization of events in the virtual reality, the question concerning the relationship among the creator, the medium, and the creation is looking for its answer. The role of the medium in the given historical moment is of vital importance especially when it comes to its reliability, credibility, and stability as a way of disseminating information about a particular object or event in a particular historical age and situation.

How does the medium influence as a material on the perceptions of the viewer? In painting, the artist treats the surface in such a way as if its base does not exist, as if it is erased. In sculpture, it has a leading role - the creation is born from the medium. Its nature which is treated by the creator (sculpting, patina-forming, coloring, polishing, etc.) comes to the fore emanating the tempting almost aching desire for a physical contact, an attempt to touch. In graphic arts, the medium is a factor with a key role in the process of creating the art and although the tactile aspect exists, it looks as if here there is a perfect balance between the medium and the creation. Maintaining equilibrium between the image and the surface free from ink, which takes an important part in the composition, is a skill and a choice that depends entirely on the artist.

aVTU "St.st. Ciryl and Metodius", Bulgaria

Correspondent Author:

Nikolina Djanovska, Pobornicheska 74, 5000 Veliko Tarnovo, Bulgaria

E-mail: kunitu@abv.bg 
It can be asserted that the development of the medium - from the cave surface to the clay plate, wood, quipus, papyrus, silk, parchment, paper, etc., makes possible the dissemination of ideas and cultural values and stimulates the development of the civilization! The means of writing, drawing, and circulating become better and so do the enlightenment and education. The society progresses through its development. The relationship between the graphic arts and the written word is as strong as the relationship between the paper and the ink. The earliest individual graphic images in the European art tradition are in fact illustrations filling up an entire sheet of paper. Almost till the end of the seventeenth century, the graphic arts were kept in albums and not put on walls in passe-partout or frames. The way they looked through was similar to leafing through a book. The graphic arts in the form of sarcastic caricatures incited the development of the civil society. The graphic arts series created by Goya, Hogarth, Daumier do not leave the viewer indifferent.

Throughout the history of graphic arts in Europe, in the different periods of time, there are graphic sheets-panoramic views of castles, estates, and towns which help us see the type and condition of the architecture of that time, the communication and life in the towns, their location, social environment, etc. We can begin with the brilliant wood engraving from the fifteenth century by Michael Wolgemut and Jacopo de'Barbari (the incredible panoramic view of Venice measuring 135/282 cm), the sixteenth century - the woodcarvings by Lucas Cranach, we should certainly mention the copperplate engravings by Waclaw Hollar from the seventeenth century characterized by their meticulous details, and end with the lithographs from the nineteenth century (e.g., a view from a hot air balloon in Dresden ${ }^{1}$ from 1865). None of them would have been created if there had not been a suitable medium for their realization. That is namely the medium on which the artist works, which forms the character of his/her graphic arts and leads it in a certain direction. The first creator who made engraving on a wooden plate is not known, but the steel engraving (the different steel engraving techniques) and the lithograph have their "documented parents". Is there any place for innovations in the contemporary art when the technology of work is still the same - printing of engraved traces from a graphic instrument from one medium (the work cliche) on another (paper or any other material taking ink)? Of course there is! We have never been freer than today to cross the space from on medium to another without any limits.

When we speak about contemporary art, the formal distinction in graphic arts according to the technique used is not fundamental. Many authors create their own personal technology of making the printing base or of the working process itself. The creators today do not impose boundaries which they cannot cross. They feel free in the choice of technique or modern day technologies, mixing classical and contemporary means of work and being limited only by their own imagination.

The history of the Bulgarian graphic arts began in the eighteenth century, with panoramic views of monasteries and their surrounding areas (a subject widely seen in the Byzantine iconography) being the most often depicted subjects as well as images of a patron saint, surrounded by life scenes. Such graphic arts lists arrived in our country for the first time in the seventeenth century as gifts bought from the pilgrimage places (Jerusalem and the monasteries of Mount Athos). In the eighteenth century, through prints spread by mendicant friars or brought in from the foreign trade centers-Dubrovnik, Venice, Pest, Vienna, and others, the graphic arts print became popular and entered the life of ordinary people. These graphic arts were the only means of advertising and propaganda before the era of the photography and mass communications. They served as post cards, travel guides and news bulletin about the habits, fashion in clothes and development of towns in far 
away and unknown lands. In our country, they became a part of the home decoration and a proof that the host was a worldly person. The stories about these places, told in front of relatives and neighbors, had greater authenticity and probably urged other people to travel around the world and get a taste of unknown experiences.

The graphic arts played an important role as a means of the national revival. In all Slav countries: Poland, the Czech Republic, Serbia, Bulgaria, Russia, whole series of graphic arts lists were drawn and disseminated, depicting images and events glorifying important history moments and confirming the national ideal. For the Bulgarians, it all began with the "Stemmatographia" by Hristofor Zhefarovich, published in 1741 in Vienna and illustrated with 76 copperplate engravings - coats of arms of Slavic and orthodox peoples and images of South Slavic rulers and saints. Then, there are numerous lithographic series of portrait images of Bulgarian rulers, national heroes and figure compositions, depicting important moments from our history and the struggle for independence. Naiden Braikovich, Heinrich Dembitsky, Anastas Jovanovich, Nikolay Pavlovich, and Georgi Danchov were the authors who created the most memorable lithographs at the end of the ninteenth century. Then, undoubtedly, it arises the question to what extent the graphics was really an art and bore artistic ideas after it was issued in a large number of prints and served as a "translation" of the painting of that time by adapting it with the means of chromolithography and by repeating one and the same subjects for centuries on end. Each new idea, each stroke made in a different way, each new subject answered this question. In Bulgarian graphic arts, some of the most memorable and interesting engravings represent such new subjects from the 1860s-1870s. We can take for example "A travel guide from Samokov to the Rila Monastrery" by Sotir Karastoyanov $^{2}$. The attempts for landscape as an individual genre of Sotir $^{3}$ and his younger brother
Vladimir Karastoyanov ${ }^{4}$ are another example, as well as the landscape from the bottom half of "Nativity of Virgin Mary" by Georgi Klinkov ${ }^{5}$ which although possessing a simple perspective, is done with a brilliant balance between the large black and white patches while the life-like rock massifs in the background provide balance to the sparse small trees which we usually can see in the icons.

While during the national revival, this type of art reached a great number of recipients using the print, probably because the conservative society from the ninteenth century who maintained patriarchal family values, respected the graphic print as a part of the valuable domestic objects and kept it zealously together with the icon, in the following years (the beginning of the twentieth century), the influence of particular art creations through specialized art issues was very small. The internationalization and unification became open to the world and turned values such as national identity, traditions, and culture into a memory by erasing them and making them archaic. The patriotic prints lost their social function and were not so interesting any more. New forms appeared and they filled up the vacant niche-the photography took the place of the panoramic landscapes, the zincography replaced the wooden print cliché and for a period of 20 years, the graphic arts in Bulgaria were at an almost complete standstill. A new generation grew up which did not inherit the need of such media forms and the tradition was lost.

The medium has an informative and educative function. As a printed issue, it takes part in the creation of an archive which represents a given historical period not only in the sphere of arts but also is very important as a means of preserving and spreading information about an art product. Nikolay Pavlovich published in the newspaper Otechestvo (issue number 67, year 2, Bucharest, 1870), a preliminary informative announcement- "Explanation of the Picture" which had to give publicity to the 
subject of the "Asparuch" lithography before it was printed and circulated. He did this for many of his graphics. The medium served for both documenting and publishing of the most recent events - what was about to happen today or would happen in the future. It was a way of reproducing and spreading a piece of art just as Letostruy magazine (issued by Hristo G. Danov 1869-1874) which regularly published lithographs ${ }^{6}$ on its pages.

This was also realized by the Bulgarian artists who established a Society for Maintaining the Art in Bulgaria in 1892. In 1895, the society began publishing Izkustvo magazine aiming at “...developing the art taste in the Bulgarians, broadening their culture and creating better conditions for the artistic life in Bulgaria..."7.

For Bulgaria, the 20s of the twentieth century marked the entering into the modern world. In 1921, our Art School of Higher Education celebrated its silver jubilee and was renamed to Academy. Bulgarian artists had already conquered their own territories and defended the reputation of the profession. The artists worked as teachers, in the theatre, collaborated with architects, contributed to the sphere of applied arts - designed objects and decorations for the home and industry. After the First World War, many young graphic arts artists worked and exhibited their creations at organized common exhibitions, but there was not a single graphic arts work in any of the official issues from this period and the 30 s of the twentieth century (namely: "50 Years of Bulgarian Art", edited by the critic Andrew Protich, issued by the State Archaeology Museum in Sofia, N29, 1933, book I and 1934, book II, 312 pages in total). In this huge catalogue, attention was paid only to the saloon art. The medium possessing an official power and being a cultural vehicle was not interested in what happened with the graphics in the artistic life (probably because it looked for new and modern creations which denied the close-to-the-nature approach in the art). Some individual graphic arts creations were presented in Vezni magazine, published by Geo Milev. "The graphic arts language typical for the press turns out to be even more suitable for vanguard plastic quests than it could be in the field of the official art space... The press with its imagery possesses the forming power of a cultural context" ${ }^{\prime \prime}$. Magazine covers as well as books of poetry and prose were illustrated. The magazines and newspapers with a cultural profile were of great importance and there the art criticism occupied a special place. Zlatorog, Hyperion, Novis (new art), the weeklies Ek and Razvigor, the newspapers Misal, Literaturen glas made the fine arts with their authors, creations and language of expression popular among the Bulgarian cultural society.

When did the medium transform into a mass media? What is its role in the formation of the artistic taste of a nation or a society? From as early as the mid-20s and 30s of the ninteenth century graphic artists, working as caricaturists, published in the periodicals in Bulgaria and Germany (Die Welt am Abend, Der Knüppel, Arbeiter Illustrierte Zeitung) pictures with anti-fascist subjects. What happened was a synthesis of the art and politics. The graphic arts drawings, published in $R L F^{9}$, Jupel, Eho, Zvunar, Antifashistki front and others, had a clearly stated ideological aim "to mobilize the people in the fight against the monarchy", "to expose the class enemy", "to enlarge the strike struggles", "to long live the red working front", "Down with war and fascism!". Some of them, in the form of party calendars and election campaign posters, became important examples of the Bulgarian publicist graphic arts of that time. After September 9, 1944 and the following years (up to the $60 \mathrm{~s})$, the graphic arts turned into a basic tool "in the fight for consolidation of the people's power and for glorifying the working heroism of the people". Owing to the media-the newspapers: Rabotnichesko delo, Otechestven front, Zemedelsko zname, Literaturen front, Papagal, Sturshel, the art turned into one of the authorities' basic instruments for imposing the official 
ideology with its famous postulates of "party-, peopleand class-consciousness" of the art.

The album "Sofia in engravings"10 gathered various authors, subjects and graphic arts techniques, showing the town of Sofia through the eyes of the artist from 1949. Almost all graphics artists from the "graphic arts" section of the Union of the Artists in Bulgaria took part in the album. Although there was a portrait of the communist leader Georgi Dimitrov and here and there a party slogan could be read, the prevalent part of the works outlined the individual creative outlook of the authors about the Bulgarian capital.

In the following period-till the $90 \mathrm{~s}$ of the twentieth century, a basic annual form of socialization of the easel paintings was the so-called CAE (Common Art Exhibition), added by Regional Art Exhibitions, later by Youth Exhibitions, etc. And since the Union of the Artists in Bulgaria was directly subordinate to the Bulgarian Communist Party through Art and Culture Section of the Propaganda Department of the Central Committee of the Bulgarian Communist Party, the art was stimulated financially by large sums in the form of contracting, purchasing and bounties. There were hundreds of exhibitions, represented in catalogues with thousands of prints. Izkustvo magazine is the basic forum for ideology till mid-70s and the publishing house "Balgarski hudozhnik" produced five hundred specialized issues with over seven million prints until 1980.

How do the relationships author- creationaudience/spectator and time- spacearchive/documenting - museum develop? Throughout the complete second half of the twentieth century, the audience was very important. Very often discussions were organized or appeared spontaneously, in which critics, local intellectuals, journalists, and different circles from the audience took place. The illusion that there was no difference between the artist and the audience was maintained. Today there are several extreme images: A cosmopolitan artist who tackles new forms of art and is uncomprehended by the mass audience; an artist-aristocrat who produces elite art which is inaccessible for the mass audience; a media artist and a public figure who is always in the spotlight (as a famous joke goes-you open a can of fish and there he is) and an artist-craftsman, an insulting name for a person who works for the mass audience, multiplying one and same subjects in the course of several decades. Is this fair? After the fall of the system, many of the so-called "free artists" found it impossible to maintain their social status of artists without the help of the state. Some of them managed to adapt quickly and retrained, some fell to the bottom of the social ladder, others like phoenix birds remained untouched by the political and social changes. For that situation, it does not matter where the artist lives. What really matters is where the audience lives - the place and possibilities given to the audience are different. Is there a specific person to blame for this or is the time we live in to be blamed? There are hundreds of discussions on this topic. In many art galleries in the country, the stocks have not been enriched with new works for already a quarter of a century, there are very rarely guest exhibitions. The middle-class Bulgarian does not visit cultural events like art exhibitions and does not encourage their children to do so. The art, in no matter what form, is not present in the everyday life of the ordinary citizens. Is it possible for the media (press, television, the internet) to alter the attitudes and to have a positive influence in that direction although they are commercially orientated?

The development of the information technologies lead to interactivity, individualization, and personalization, the cultural necessities can be molded. The medium can be and is a mediator which presents the result of a creative act and transforms it from a monologue to a dialogue showing it to the common cultural space. A given thing exists in the moment when "the event happens" in the institution (a gallery, saloon, etc.) - it is presented, reproduced, possibly 
sold or it does not exist because it is not covered by any media, it is not published anywhere (it is not "promulgated"), therefore it does not justify the meaning of its existence, it does not influence anyone. Through the medium, we can archive and later explore the present. We can compare it and analyze it in the context of the past and the expected future. It turns the artefacts into exhibits and collections which should perseveringly be replenished with art and events of the day gone by.

How big is the force that the medium possess? Enormous! With the modern properties of the social networks, an event reaches in seconds millions of users on all continents. The reliability of something that can be reached by so many people is, of course, arguable, but the possibility of such publicity should not be neglected.

An attempt to raise the interest of the public toward the art is the presentation of 15 works of art from the stock of the SCAG (Sofia City Art Gallery) on 30 commercial billboards during the extraordinary advertising campaign "more space for art" which took place in February 2014 in Sofia (following the example of a similar initiative in Great Britain). But this is rather an exception.

The change toward new forms is not determined by the change of the medium as a means of printing or presenting but by redefining of the "perceptive context", the mind of the spectator, by shifting the viewers' horizon of expectation, by turning the viewer from an observer to an associate. In this sense, the medium as a means of spreading information will play increasingly bigger role as a phenomenon capable of changing and cultivating the individual's attitude, of incorporating $\mathrm{him} / \mathrm{her}$ to the world of art and of turning him/her from a spectator to an audience.

\section{Notes}

1. Litographed by Walter - based on a drawing by Eltzner, Frank-Dietrich J., Historische Stadtansichten, VEB E.A.
Seemann, Verlag, Leipzig, 1982, pp. 144-145.

2. Wood engraving, 300/150 mm, The Historical Museum of Samokov, Tomov E., Prints of the Bulgarian National Revival, Balgarski hudozhnik publishing house, Sofia, 1975, page 72 .

3. Wood engraving, 125/35 mm, a collection by Evtim Tomov, Tomov E., Prints of the Bulgarian National Revival, Balgarski hudozhnik publishing house, Sofia, 1975, page 73.

4. Wood engraving, 37/128, a collection by Evtim Tomov, Tomov E., Prints of the Bulgarian National Revival, Balgarski hudozhnik publishing house, Sofia, 1975, page 74.

5. Wood engraving, 390/265, The Historical Museum of Samokov, Tomov E., Prints of the Bulgarian National Revival, Balgarski hudozhnik publishing house, Sofia, 1975, album illustration 226.

6. Atseva V., Lithographic portraits from the national revival in the national library "Ivan Vazov"-Plovdiv, Bulgarian fine and applied arts from the National Revival period, published by BAS, Sofia, 1985, page 123 .

7. Leading article by prof. Borislav Stoev of the album Organized Art Life in Bulgaria 1894-1994, Balgarski hudozhnik publishing house, Sofia, 1994.

8. Stefanov Sv., The modernism in the Bulgarian press during the 20s and 30s, Izkustvo/Art in BG, year II, 11-12/1993, Publicity House AЯ, Sofia, 2000, page 5.

9. The newspaper Rabotnicheski Literaturen Front.

10. The album "Sofia in engarvings" -24 authors, 50 engravings, Nauka i izkustvo State publishing house, Sofia, 1950, A part of the original prints of the engravings included in the album were sent on behalf of Sofia City People's Council to the leader of the progressive humanity, the comrade Stalin.

\section{References}

120 Years of Bulgarian Art. 2012. "Supporting Art in Bulgaria" Foundation, Sofia.

Bojkov, A. 1958. Bulgarian Revolutionary Graphics Art. Sofia: Balgarski Hudozhnik Publishing House.

Bulgarian Fine and Applied Arts From the National Revival Period. 1985. Sofia: BAS.

Frank-Dietrich, J. 1982. Historische Stadtansichten (Historic City Views). VEB E.A. Seemann, Verlag, Leipzig.

Izkustvo/Art in BG, Year II, 11-12/1993. 2000. Sofia: Publicity House AЯ.

Marinska, R. 1996. The Bulgarian Fine Arts in the 20s. Sofia: Otvoreno Obshtestvo Publishing House.

Organized Art Life in Bulgaria 1894-1994. 1994. Sofia: Balgarski Hudozhnik Publishing House. 
Protich, A., ed. 1933. 50 Years of Bulgarian Art. State Archaeology Museum in Sofia.

Sofia in Engravings. 1950. Sofia: Nauka i izkustvo State Publishing House.

Tomov, E. 1975. Prints of the Bulgarian National Revival. Sofia: Balgarski Hudozhnik Publishing House.

\section{Bio}

Nikolina Djanovska, MA, Ph.D. candidate, Department of Graphics, Faculty of Fine Arts, VTU "St.st. Ciryl and Metodius", Veliko Tarnovo, Bulgaria; research field: working on issues related to contemporary Bulgarian graphics. 